\title{
Susceptibility of four passion fruit species to the reniform nematode
}

\author{
Mário Massayuki Inomoto ${ }^{1} \&$ Amanda Borjatto da Fonseca²
}

\begin{abstract}
Reniform nematode (Rotylenchulus reniformis) is a major pest of sour-passion fruit (Passiflora edulis) in Brazil, and few management methods are currently available, mainly due to the lack of host-plant resistance. Other species of passion fruit species are also commercially available in Brazil, which could be a source of resistance. Cultivars of three species (P. setacea 'BRS-Pérola-do-Cerrado', $P$. cincinnata 'BRS-Sertão-Forte', and $P$. alata 'BRS-Mel-do-Cerrado'), and one susceptible cultivar ( $P$. edulis BRS-Gigante-Amarelo) were evaluated for reniform nematode susceptibility in two greenhouse trials. Results showed that the cultivars were susceptible. Therefore, reniform nematode management in passion fruit must be rely on a combination of nematode-free seedlings and nematode-free fields.
\end{abstract}

Index-terms: Passiflora alata, Passiflora cincinnata, Passiflora edulis, Passiflora setacea, Rotylenchulus reniformis.

\section{Reação de quatro espécies de maracujazeiro ao nematoide reniforme}

Resumo - O nematoide reniforme (Rotylenchulus reniformis) é uma das principais pragas do maracujá-azedo (Passiflora edulis), e há poucos métodos de manejo, pois não há fontes de resistência. Outras espécies de maracujá estão disponíveis comercialmente no Brasil e poderiam ser fontes de resistência. Cultivares de três espécies (P. setacea 'BRS-Pérola-do-Cerrado', P.cincinnata 'BRS-Sertão-Forte' e P.alata 'BRS-Mel-do-Cerrado') e uma cultivar suscetível (P.edulis 'BRSGigante-Amarelo) foram avaliadas quanto à suscetibilidade ao nematoide reniforme, em dois experimentos conduzidos em casa de vegetação. Os resultados mostraram que as cultivares de maracujá testadas são suscetíveis a $R$. reniformis; portanto, a base para o manejo do nematoide

Corresponding author: inomoto@usp.br

Received: September 16, 2019 Accepted: January 27,2020

Copyright: All the contents of this journal, except where otherwise noted, is licensed under a Creative Commons Attribution License. reniforme em maracujá deve ser a combinação do uso de mudas sadias e campos livres dos nematoides.

Termos para indexação: Passiflora alata, Passiflora cincinnata, Passiflora edulis, Passiflora setacea, Rotylenchulus reniformis.

${ }^{1}$ Agronomist, Dr., Associated Professor, Departamento de Fitopatologia e Nematologia, Escola Superior de Agricultura Luiz de Queiroz, Universidade de São Paulo, Piracicaba (SP), E-mail: inomoto@usp.br (ORCID 0000-0001-9870-8194)

${ }^{2}$ Undergraduate student, Faculdade de Ciências da Saúde, Universidade Metodista de Piracicaba, Piracicaba (SP), fellowship program Fealq (Fundação de Estudos Agrários Luiz de Queiroz, Piracicaba), E-mail: borjattoamanda@yahoo.com.br 
In Brazil, reniform nematode (Rotylenchulus reniformis Linford \& Oliveira, 1940) was reported for the first-time attacking passion fruit (Passiflora sp.) roots in the municipality of Votuporanga, São Paulo state (CURI and BONA, 1972). Now, R. reniformis is widespread in Brazilian sour passion fruit (Passiflora edulis) orchards. According to a 1990 s survey, $R$. reniformis was present in $35 \%$ of passion fruit samples from Brazilian Federal District, Minas Gerais state and Goiás state (SHARMA et al., 1999). In 2007-2009, a survey of 14 yellow passion fruit (P. edulis Sims f. flavicarpa Deg) orchards in the Federal District of Brazil showed its occurrence in nine out of 20 samples (CASTRO et al., 2012).

The effects of the reniform nematode on sour passion fruit has been fairly documented. A survey of yellow passion fruit orchards in Fiji showed the occurrence of reniform nematode in 16 out of 19 sampled orchards. Additionally, a glasshouse trial was carried out in order to evaluate the effect of reniform nematode on the growth of passion fruit seedling. After 81 days in $4,000 \mathrm{~cm}^{3}$ pots containing non-infested soil or with two densities of $R$. reniformis (2,275 and 22,750 specimens), the nematode did not affect the root fresh weight, but the higher nematode density resulted in a 23\% reduction in fresh weight of passion fruit vines (KIRBY, 1978). As the densities exceeded 1,000 individuals of $R$. reniformis per $200 \mathrm{~cm}^{3}$ soil in 11 orchards of the survey, and the maximum density reached 36,000 specimens, the reniform nematode should be considered a major pest of passion fruit in Fiji.

A study conducted in Venezuela over a 7-week period showed a significant reduction in plant height within two weeks after inoculation $(9 \%)$, and intensified along the trial progress, reaching $22 \%$. Additionally, fresh and dry weight of passion fruit vines decreased 51 and $60 \%$ respectively; fresh and dry weighs of roots decreased 22 and $50 \%$ respectively. Other effects of reniform nematode on passion fruit plants were the foliar yellowing and stem thinning (SUÁREZ-H. and ROSALES, 2003).

Few management methods were available for the sour passion fruit plants / R. reniformis pathosystem, because of the lack of host-plant resistance. However, 70 or more species of Passiflora that have a potential economic value were not rated yet for their host suitability to $R$. reniformis in a way to be used as a reniform nematode management strategy.

Some cultivars of wild passion fruit were launched recently in Brazil: 'BRS-Pérola-do-Cerrado' / BRS-PC (Passiflora setacea DC) (RANGEL-JUNIOR et al., 2018), 'BRS-Sertão-Forte'/ BRS-SF ( $P$. cincinnata Mast) (ARAÚJO et al., 2016), and 'BRS-Mel-do-Cerrado' / BRS-MC ( $P$. alata Curtis) (FALEIRO et al., 2017). Due to the importance of $R$. reniformis to the passion fruit crop, two greenhouse trials were carried out in order to evaluate the susceptibility of these cultivars to the reniform nematode. The intraspecific hybrid 'BRS-GiganteAmarelo' / BRS-GA1 of yellow passion fruit was used as susceptible standard host.

The isolate of $R$. reniformis was obtained from yellow passion fruit roots collected in Piracicaba (SP). Seeds of yellow passion fruit (indeterminate cultivar) were sow in an autoclaved $\left(121^{\circ} \mathrm{C} / 2 \mathrm{~h}\right)$ sandy-loam soil, and plants were infected with egg masses of $R$. reniformis. The infected plants were maintained in $1,000-\mathrm{cm}^{3}$ clay pots in a greenhouse. The inocula for the trials were obtained from potted soil by a modified Baermann method for flat recipient (SOUTHEY, 1986), resulting in an aqueous suspension containing juveniles, males and young females.

One single seed of each of the four passion fruit species was sowed in a $450-\mathrm{cm}^{3}$-plastic cup $(6.5 \mathrm{~cm}$ diameter $\mathrm{x} 13.6 \mathrm{~cm}$ height) filled with an autoclaved (121 ${ }^{\circ} \mathrm{C} / 2 \mathrm{~h}$ ) sandy-loam soil. The germination was very poor and irregular, but seven seedlings of BRS-GA1, eight of BRS$\mathrm{MC}$, four of BRS-PC, and eight of BRS-SF were obtained three weeks after the sowing. Forty-five days after sowing, each seedling was inoculated with 2,000 specimens of $R$. reniformis by pouring an aqueous suspension containing the nematodes in a hole ( $7 \mathrm{~mm}$ diameter $/ 20 \mathrm{~mm}$ depth) made in the soil, at $1 \mathrm{~cm}$ distant from plant stem. The passion fruit plants were maintained in a glasshouse until the evaluation, 59 days after inoculation (DAI). Soil and roots were separated in $4 \mathrm{~L}$ of tap water in a $10 \mathrm{~L}$ bucket. For evaluations, the soil nematodes were recovered by centrifugal-flotation method (JENKINS, 1964), resulting in a $20 \mathrm{~mL}$ aqueous suspension containing adults (females and males), juveniles and eggs of $R$. reniformis. The nematodes were heat-inactivated $\left(60^{\circ} \mathrm{C}\right)$, fixed by adding formalin until reach $0.25 \%$ concentration, maintained at $10{ }^{\circ} \mathrm{C}$, and counted twice in a Peters' counting slide $(1 \mathrm{~mL}$ aliquot) at 100x magnification using a light microscope (Olympus $\mathrm{CH} 2$ ).

Roots were exanimated at $13 \mathrm{x}$ magnification under a stereomicroscope (Leica EZ4) in order to counting $R$. reniformis egg masses. Thereafter, the root nematodes were recovered by blender-centrifugalflotation method (COOLEN and D'HERDE, 1972), using $0.5 \% \mathrm{NaOCl}$ solution and a kitchen blender at low speed. The nematodes from the roots were inactivated, fixed and counted as previously performed for the soil nematodes. The $R$. reniformis final population (Pf) was the sum of the population recovered from the soil (Pf Soil) plus the population from the roots (Pf Roots); thus, the reproductive factor $(\mathrm{RF}=\mathrm{Pf} / \mathrm{Pi})$ was calculated. To compare the susceptility of the passion fruit species to $R$. reniformis, the following variables were considered: 1-number of egg masses per plant, 2-Pf Soil, 3-Pf Roots, and $4-R F$ value.

The trial was repeated once using another ten seeds of each Passiflora species, which were sowed in a $450-\mathrm{cm}^{3}$-plastic cup filled with an autoclaved $\left(121^{\circ} \mathrm{C} / 2 \mathrm{~h}\right)$ 
sandy-loam soil. One single seedling was transplanted to other $450-\mathrm{cm}^{3}$-plastic cup with autoclaved sandy-loam soil 36 days after sowing. Seven seedlings of BRS-GA1, six of BRS-MC, eight of BRS-PC were obtained; however, seeds of BRS-SF did not germinate at all. Eight days after transplanting (44 days after sowing), the inoculation was performed as the trial 1 . The evaluation was similar to of the trial 1, but 129 DAI.

Both experiments were set up in a completely randomized design, with four treatments and 4-8 replicate (trial 1) / three treatments and 5-8 replicates (trial 2). Data obtained (egg masses, Pf Soil, Pf Roots, and RF) were analyzed without transformation using R-package (r-project.org), and the mean values were compared by Tukey's honestly significant difference test $(\mathrm{P}=0.05)$.
The results of both trials are presented in the Table 1. Reniform nematode reproduced at high rates in all Passiflora species. The three species were not different from the susceptible control for egg masses, Pf Soil and Pf Roots. The P. cincinnata showed a lower RF, but this cultivar failed to germinate in the second trial to confirm this result. The population increase obtained in trial $1(\mathrm{R}=1.61-6.19$ / $59 \mathrm{DAI})$ was similar to the values previously obtained for ten cultivars and hybrids of $P$. edulis (RF=2.4-6.4 / 51 DAI) (SHARMA et al., 2001). The soil populations (Pf Soil) were markedly higher in trial 2, probably due to the longer experimental period (129 DAI $v s .59 \mathrm{DAI})$, resulting in higher values of $\mathrm{R}$. Therefore, the population densities of $R$. reniformis in soil might attain very high values during the economic production period of passion fruit, which ranges from 18 months to 4 years for P. edulis (KIRBY, 1978).

Table 1. Number of passion fruit plants evaluated $(\mathrm{N})$, number of egg masses per plant, Rotylenchulus reniformis recovered from the roots and soil, $R$. reniformis reproductive factor (FR) on Passiflora alata BRS-Mel-do-Cerrado (Pa / BRS-MC), P. cincinnata BRS-Sertão-Forte (Pc / BRS-SF), P. edulis BRS-Gigante-Amarelo-1 (Pe / BRS-GA1) and $P$. setacea BRS-Pérola-do-Cerrado (Ps / BRS-PC).

\begin{tabular}{|l|c|c|c|c|c|c|c|c|c|c|}
\hline & \multicolumn{9}{|c|}{ Trial 1 (59 dai) } & \multicolumn{4}{c|}{ Trial 2 (129dai) } \\
\hline Species / cultivars & N & $\begin{array}{c}\text { Egg } \\
\text { Masses }\end{array}$ & $\begin{array}{c}\text { Pf } \\
\text { Roots }\end{array}$ & Pf Soil & R & N & $\begin{array}{c}\text { Egg } \\
\text { Masses }\end{array}$ & $\begin{array}{c}\text { Pf } \\
\text { Roots }\end{array}$ & Pf Soil & R \\
\hline Pe / BRS-GA1 & 7 & $476 \mathrm{a}$ & $4,089 \mathrm{a}$ & $8,291 \mathrm{a}$ & $6.19 \mathrm{a}$ & 5 & $418 \mathrm{a}$ & $6,199 \mathrm{a}$ & $30,367 \mathrm{a}$ & $18.13 \mathrm{a}$ \\
\hline $\mathrm{Pa} / \mathrm{BRS}-\mathrm{MC}$ & 8 & $351 \mathrm{a}$ & $6,219 \mathrm{a}$ & $5,667 \mathrm{a}$ & $5.94 \mathrm{a}$ & 6 & $347 \mathrm{a}$ & $7,114 \mathrm{a}$ & $45,803 \mathrm{a}$ & $26.38 \mathrm{a}$ \\
\hline $\mathrm{Ps} /$ BRS-PC & 4 & $172 \mathrm{a}$ & $1,350 \mathrm{a}$ & $5,045 \mathrm{a}$ & $3.20 \mathrm{ab}$ & 8 & $538 \mathrm{a}$ & $4,191 \mathrm{a}$ & $16,210 \mathrm{a}$ & $10.43 \mathrm{a}$ \\
\hline $\mathrm{Pc} /$ BRS-SF & 8 & $167 \mathrm{a}$ & $755 \mathrm{a}$ & $2,473 \mathrm{a}$ & $1.61 \mathrm{~b}$ & - & - & - & - & - \\
\hline
\end{tabular}

Means followed by the same letter in column do not differ according to Tukey test $(0.05)$.

The absence of a remarkable resistance of BRSMC, BRS-PC, and BRS-SF, which might be ranked as susceptible hosts to the reniform nematode, comparable to BRS-GA1, shows that other techniques should be considered for $R$. reniformis management. However, as mentioned above, Brazilian nurseries have not adopted any specific measure to prevent nematode contamination in passion fruit seedlings, as nearly no legislation exists to prevent the commercialization of nematode-infected passion fruit seedlings in Brazil. Some nurseries applies the use of artificial substrates to produce passion fruit seedlings, which are supposed to be free of phytonematodes. In addition, they could use water from artesian aquifer to irrigate the seedlings; however in Brazil these procedures were not compulsory in passion fruit nurseries (BRAGA and JUNQUEIRA, 2003; SILVA, 2006). Therefore, the passion fruit producers must select carefully the nurseries and the fields where the orchard will be implanted.

\section{Acknowledgment}

The authors would like to thank Dr. Fabio Gelape Faleiro for the donation of the seeds used in the present work, and Dr. Victor Hugo Moura de Souza for revising the manuscript and suggesting improvements.

\section{References}

ARAÚJO, F.P.; MELO, N.F.; FALEIRO, F.G. Cultivar de maracujazeiro silvestre (Passiflora cincinnata Mast.) para a Caatinga e para o Cerrado. Petrolina: Embrapa Semi-Árido, 2016. Folder. (Comunicado Técnico)

BRAGA, M.F.; JUNQUEIRA, N.T.V. Produção de mudas de maracujá-doce. Planaltina: Embrapa Cerrados, 2003. 28p. 
CASTRO, A.P.G.; GOULART, A.M.C.; ANDRADE, E.P.; CARES, J.E.; CARVALHO, D.D.C. Plant-parasitic nematodes associated with commercial orchards of passion fruit and adjacente cerrado vegetation in the Brazilian Federal District. Plant Pathology Journal, Seoul, v.28, n.3, p.306-310, 2012.

COOLEN, W.A.; D'HERDE, C.J. A method from the quantitative extraction of nematodes from plant tissue. Ghent: State Agricultural Research Centre, 1972. p.77.

CURI, S.M.; BONA, A. Ocorrência do nematóide reniforme, Rotylenchulus reniformis, em culturas de algodão e maracujá, no Estado de São Paulo. O Biológico, São Paulo, v.38, n.4, p.127-128, 1972.

FALEIRO, F.G.; JUNQUEIRA, N.T.V.; COSTA, A.M.; BRAGA, M.F. Cultivar de maracujazeiro-doce (Passiflora alata Curtis) para mercado de frutas especiais de alto valor agregado. Planaltina: Embrapa Cerrados, 2017. Folder. (Comunicado Técnico)

JENKINS, W.R. A rapid centrifugal-flotation technique for separating nematodes from soil. Plant Disease Reporter, Beltsville, v.48, n. 9, p.692, 1964.

KIRBY, M.F. Reniform and knot root nematodes on passionfruit in Fiji. Nematropica, Polk City, v.8, n.1, p.21-25, 1978.
RANGEL-JUNIOR, I.M.; VASCONCELOS, M.A.S.; ROSA, R.C.C.; CRUVINEL, F.F. Floral biology and physiocochemical characterization of wild passion fruit Passiflora setacea d.C. BRS Pérola do Cerrado cultivated in the state of Rio de Janeiro. Revista Brasileira de Fruticultura, Jaboticabal, v.40, n.6, p.1-9, 2018.

SHARMA, R.D.; JUNQUEIRA, N.T.V.; GOMES, A.C. Nematoides nocivos ao maracujazeiro. Planaltina: Embrapa Cerrados, 1999. 4p. (Comunicado Técnico)

SHARMA, R.D.; JUNQUEIRA, N.T.V.; GOMES, A.C. Reaction of passionfruit genotypes to the reniform nematode, Rotylenchulus reniformis. Nematologia Brasileira, Brasília, DF, v.25, n.2, p.211-215, 2001.

SILVA, A. P. P. Desenvolvimento de mudas de maracujazeiro amarelo em tubetes. 2006. (Dissertação) - Universidade Federal de Uberlândia, Uberlândia, 2006.

SOUTHEY, J.F. Laboratory methods for work whit plant and soil nematodes. London: Her Majesty's Stationery Office, 1986.

SUÁREZ-H., Z.; ROSALES, L. C. Efecto del nematodo reniform (Rotylenchulus reniformis Linford y Oliveira) sobre maracuyá (Passiflora edulis Sims f. sp. flavicarpa O. Deg.). Revista Mexicana de Fitopatologia, Chapingo, v.21, n.3, p.305-308, 2003. 